\title{
Impact of climate change on rice yield at Jorhat, Assam
}

\author{
B. GOSWAMI ${ }^{1}$, R. HUSSAIN ${ }^{1}$, V.U.M. RAO ${ }^{2}$ and U.S. SAIKIA ${ }^{3 *}$ \\ ${ }^{1}$ Department of Agricultural Meteorology, AAU, Jorhat, 785 013, Assam \\ ${ }^{2}$ Central Research Institute for Dryland Agriculture, Hyderabad, 500059 \\ ${ }^{3}$ ICAR Research Complex for NEH Region, Umroi Road, Umiam 793 103, Meghalaya \\ *Email: ussaikia73@gmail.com
}

\begin{abstract}
Impact of climate change on rice yield variabilities under various Representative Concentration Pathways (RCPs) has been estimated for Jorhat district, under Upper Brahmaputra Valley Agroclimatic Zone of Assam. CERES-Rice module of DSSAT 4.5 was calibrated and validated for rice cultivar 'Mahsuri' under three different dates of transplanting between May and July. Increase in both maximum and minimum temperatures at Jorhat, under all the RCPs for 2020, 2050 and 2080, suggests increasing level of heat stress during crop growth period. The deviations in projected grain yield over observed mean yield of 2009-2013 was found ranging from -12.7 to -43.4 per cent under all the scenario and dates of transplanting. Among all the climate scenarios, the reduction in grain yield was highest $(-43.4 \%)$ under RCP 8.5 and lowest $(-12.7 \%)$ under RCP 2.6. The mean yield reduction, considering all scenarios together, was highest in second transplanting date $(-38.5 \%)$, followed by third(-28.8\%) and first one $(-23.3 \%)$.
\end{abstract}

Key words: Climate change, RCP, rice yield variability, rainfed, CERES-Rice

The present rapid climate change and its adverse affects are mostly governed by the rapidly increasing concentration of green house gases (GHG's), aerosols and other pollutants. These emissions are regulated by various natural and anthropogenic factors. Anthropogenic GHG emissions are mainly driven by population size, economic activity, lifestyle, energy use, land use patterns, technology and climate policy. The Representative Concentration Pathways (RCPs), which are used for making future climatic projections, based on these factors. The RCPs describe four different $21^{\text {st }}$ century pathways of GHG emissions and atmospheric concentrations, air pollutant emissions and land use (IPCC, 2014). The RCPs include a stringent mitigation scenario (RCP2.6), two intermediate scenarios (RCP4.5 and RCP6.0) and one scenario with very high GHG emissions (RCP8.5). Among different RCPs, RCP2.6 is representative of a scenario that aims to keep global warming likelybelow $2^{\circ} \mathrm{C}$ above pre-industrial temperatures. Though these emissions scenarios are highly uncertain but they serves as an important tool to analyze how various driving forces may influence future emission outcomes and possible impacts on the biological world. They also assist in the study of the location specific assessment of impacts of climate change and potential adaptation and mitigation measures (Anon, 2015).

Climate change is projected to reduce renewable surface water and groundwater resources in most dry subtropical regions, intensifying competition for water among various sectors, including agriculture (IPCC, 2014). In India, the sustainability of its agricultural production depends on performance of monsoon rainfall every year to a great extent. It is also widely apprehended that under projected severe completion for water, the poor and marginalized farmers may not be able to compete with water extraction by industries and large-scale agriculture and there by impacting overall production of crops. Going by the revelation of various researchers it has been found that though the Indian monsoon rainfall is projected to increase (IPCC, 2013), but in the recent years it has shown frequent weaker performance (Ramesh and Goswami, 2007), erratic distribution and increase in extreme rainfall events during the four months of monsoon (Dash et al., 2009) leading to poor yield realization. Climate change has evidently already negatively affected India's hundreds of millions of rice producers. Auffhammer et al. (2012) reported that affect of drought and extreme rainfall on rice yield is more prominent in predominantly rainfed areas and drought is having a much greater impact than extreme rainfall. They found that had there been no change in frequency of drought since 1960, India would have gained additional $1.7 \%$ of rice yield over its average. A drought during the summer of 2009 was one of the most severe in decades, where India's rice 
Table 1: Soil physico-chemical properties of the experimental site

\begin{tabular}{|c|c|c|c|c|c|}
\hline Sl. No. & Parameters & \multicolumn{4}{|c|}{ Description } \\
\hline 1 & Soil colour & \multicolumn{4}{|l|}{ Grey } \\
\hline 2 & Soil texture & \multicolumn{4}{|c|}{ Sandy clay loam } \\
\hline 3 & Drainage & \multicolumn{4}{|c|}{ Moderately well } \\
\hline 4. & Soil series & \multicolumn{4}{|c|}{ Rowriah } \\
\hline 5 & Soil classification & \multicolumn{4}{|c|}{ Fine, mixed, hyperthermic family of Humic Endoaquepts } \\
\hline \multirow[t]{3}{*}{6} & Slope $(\%)$ & \multicolumn{4}{|c|}{ Nearly level to very gently sloping } \\
\hline & & \multicolumn{4}{|c|}{ Soil layers (cm) } \\
\hline & & $0-20$ & $20-48$ & $48-62$ & $62-100$ \\
\hline 7 & Clay $(\%)$ & 24.4 & 35.4 & 41.4 & 35.2 \\
\hline 8 & Silt (\%) & 52.7 & 49.0 & 35.0 & 32.4 \\
\hline 9 & Sand $(\%)$ & 22.9 & 15.6 & 23.6 & 32.4 \\
\hline 10 & $\mathrm{pH}$ & 5.2 & 5.1 & 5.1 & 5.0 \\
\hline 11 & $\mathrm{CEC}\left(\mathrm{Cmol} \mathrm{kg}^{-1}\right)$ & 6.1 & 8.4 & 9.6 & 7.9 \\
\hline 12 & Organic C (\%) & 0.88 & 0.42 & 0.32 & 0.19 \\
\hline 13 & Soil moisture $(\% / v)$ & 24.4 & 25.5 & 26.8 & 28.8 \\
\hline
\end{tabular}

production was declined by $14 \%$ (Commission for Agricultural Costs and Prices, 2010).

The high rainfall North Eastern (NE) region of India, observes very frequent occurrence of dry spells in recent times, and decline in annual as well as monsoon rainfall may be attributed to rapid climate change (Manoj-Kumar, 2011). A study, based on standardized precipitation index, comprehensively shown changes in overall seasonal proneness to meteorological drying or wetting, and most of the North East India lost their degree of monsoon wetness during 1991-2007 (Saikia et al., 2013). Ravindranathet al. (2011) assessed the effects of climate change in the districts of NE India with multiple socio-economic consequences and defined the vulnerability of the districts with respect to agriculture and water availability. He opined that since $80 \%$ of the crop area is under rainfed agriculture in the region, present and future climate change and variability potentially affect agriculture production here by virtue of acute soil moisture deficit and lack of irrigation/water harvesting infrastructure. Hence, comprehensive studies on selection of suitable crop/cultivars with multi-stress tolerance ability, crop diversification and intensification are required in the context of present and future scenarios. Under these circumstances, this study was taken up to evaluate the impact of climate change on present and future kharif rice production scenarios in Jorhat, Assam, which is a major rice growing area in the state.

\section{MATERIALS AND METHODS}

The rice soils of Assam are alluvial in nature and kharif (Sali) is the main rice growing season (June/July to November/December). The State gets more than $60 \%$ of the total annual precipitation during four months of monsoon season. Jorhat, the study area $\left(26^{\circ} 44^{\prime} \mathrm{N}\right.$ latitude, $94^{\circ} 10^{\prime} \mathrm{E}$ longitude and $91 \mathrm{~m}$ above mean sea level), is located in the Upper Brahmaputra Valley(UBV) agro-climatic zone, which receives $1500-2500 \mathrm{~mm}$ rainfall annually. The ranges of maximum and minimum temperatures at Jorhat are 23.6-31.7 and $10.0-24.2^{\circ} \mathrm{C}$, respectively. On an average, the relative humidity remains above $70 \%$ throughout the year.

The experiment had two components: (a) field experiment from 2009-2013 with rice cultivar Mahsuri (normal duration: 150-160 days) for calibration (2009-2011) and validation (2012-2013) of the CERES-Rice module of DSSAT 4.5 and (b) estimation of rice (cv. Mahsuri) yield variability for 2020, 2050 and 2080 at Jorhat, Assam. The field experiments were conducted in randomized block design (RBD), with three replications, at the Instructional cum Research Farm of Assam Agricultural University, Jorhat. The soil physic-chemical status of the experimental site is presented in Table 1. Three transplanting windows were selected for transplanting of rice and they were maintained in the $3^{\text {rd }}$ week of May, $2^{\text {nd }}$ week of June and $1^{\text {st }}$ week of July with near about 15 days interval between each transplanting. 
Table 2 : Seasonal change in maximum and minimum temperatures and rainfall in 2020, 2050 and 2080 RCP projections at Jorhat over 2009-2013

\begin{tabular}{|c|c|c|c|c|}
\hline Scenarios & Summer & Monsoon & Post monsoon & Winter \\
\hline \multicolumn{5}{|l|}{ Maximum temperature $\left({ }^{\circ} \mathrm{C}\right)$} \\
\hline 2009-2013 Actual mean & 28.8 & 32.3 & 27.3 & 24.5 \\
\hline Mean of all scenarios (2020) & 31.6 & 33.5 & 28.6 & 23.5 \\
\hline Absolute change over 2009-2013 & 2.7 & 1.2 & 1.3 & -1.0 \\
\hline Mean of all scenarios (2050) & 32.0 & 33.8 & 28.8 & 23.9 \\
\hline Absolute change over 2009-2013 & 3.1 & 1.5 & 1.5 & -0.7 \\
\hline Mean of all scenarios (2080) & 32.9 & 34.7 & 29.8 & 24.9 \\
\hline Absolute change over 2009-2013 & 4.0 & 2.4 & 2.5 & 0.4 \\
\hline \multicolumn{5}{|l|}{ Minimum temperature $\left({ }^{\circ} \mathrm{C}\right)$} \\
\hline 2009-2013 Actual mean & 19.6 & 25.5 & 16.2 & 11.1 \\
\hline Mean of all scenarios (2020) & 21.5 & 26.6 & 17.4 & 11.0 \\
\hline Absolute change over 2009-2013 & 1.9 & 1.1 & 1.2 & -0.1 \\
\hline Mean of all scenarios (2050) & 21.9 & 26.9 & 17.7 & 11.4 \\
\hline Absolute change over 2009-2013 & 2.3 & 1.4 & 1.4 & 0.2 \\
\hline Mean of all scenarios (2080) & 22.9 & 27.7 & 18.7 & 12.6 \\
\hline Absolute change over 2009-2013 & 3.3 & 2.2 & 2.5 & 1.5 \\
\hline \multicolumn{5}{|l|}{ Rainfall (mm) } \\
\hline 2009-2013 Actual mean & 537.7 & 1187.2 & 106.6 & 23.5 \\
\hline Mean of all scenarios (2020) & 786.5 & 1416.8 & 135.8 & 51.2 \\
\hline Absolute change over 2009-2013 & 248.8 & 229.6 & 29.2 & 27.7 \\
\hline$\%$ change over $2009-2013$ & 46.3 & 19.3 & 27.4 & 118.0 \\
\hline Mean of all scenarios (2050) & 883.1 & 1496.6 & 137.1 & 41.7 \\
\hline Absolute change over 2009-2013 & 345.4 & 309.4 & 30.5 & 18.3 \\
\hline$\%$ change over $2009-2013$ & 64.2 & 26.1 & 28.6 & 77.9 \\
\hline Mean of all scenarios (2080) & 701.9 & 1175.2 & 133.7 & 57.6 \\
\hline Absolute change over 2009-2013 & 164.3 & -12.1 & 27.1 & 34.1 \\
\hline$\%$ change over $2009-2013$ & 30.6 & -1.0 & 25.4 & 145.3 \\
\hline
\end{tabular}

Normal doses of fertilizer recommended for UBV agroclimatic zone were followed.

The genetic coefficients of rice $\mathrm{Cv}$. Mahsuri were generated (2009-2011) using inbuilt 'Genotype Coefficient Calculator' and RMSE and D-stat analysis were done to test the levels of agreement during the calibration runs. Four RCPs (RCP 2.6, 4.5, 6.0 and 8.5) were used, which were generated using Hadley Global Environment Model 2-Earth System (HadGEM2-es) (Collins et al., 2011). RCP projected climatic data on daily maximum and minimum temperature, rainfall and solar radiation for 2020, 2050 and 2080 were collected from CRIDA, Hyderabad. Pattern of change of seasonal maximum and minimum temperatures and rainfall were compared among pre-experiment period (1991-2008), experiment period (2009-2013) and RCP projected data sets for 2020, 2050 and 2080. The simulated yields of different scenarios were compared with observed mean yield of 2009 2013 for their respective transplanting windows.

\section{RESULTS AND DISCUSSION}

Pattern of maximum and minimum temperatures and rainfall

Pattern of maximum and minimum temperatures and 
Table 3: Calibration (2009-11) and validation (2012-13) results for rice Cv. Mahsuri at Jorhat

\begin{tabular}{lrrrr}
\hline Variable & Observed & Simulated & RMSE & D-stat \\
\hline Calibration (2009-11) & & & & \\
Anthesis day & 122 & 123 & 3.3 & 0.92 \\
Grain yield $\left(\mathrm{kg} \mathrm{ha}^{-1}\right)$ & 3128 & 3291 & 1651.9 & 0.50 \\
Maturity day & 164 & 150 & 19.1 & 0.51
\end{tabular}

\section{Validation (2012-13)}

D1* ( $3^{\text {rd }}$ week of May)

Anthesis day

Grain yield $\left(\mathrm{kg} \mathrm{ha}^{-1}\right)$

Maturity day

D2 ( $2^{\text {nd }}$ week of June)

Anthesis day

Grain yield $\left(\mathrm{kg} \mathrm{ha}^{-1}\right)$

Maturity day

D3 (1 ${ }^{\text {st }}$ week of July)

Anthesis day

Grain yield $\left(\mathrm{kg} \mathrm{ha}^{-1}\right)$

Maturity day
125

2569

152

117

4553

161

103

3134

135
121

2337

165

119

4145

158

107

3417

141

*D1 ( $3^{\text {rd }}$ week of May), D2 ( $2^{\text {nd }}$ week of June $)$ and D3 ( $1^{\text {st }}$ week of July) are the dates of transplanting

Table 4: Genotype coefficients for rice Cv. Mahsuri (model: CERES-Rice) at Jorhat

\begin{tabular}{lc}
\hline Genotype coefficients & Values \\
\hline P1 & 763.1 \\
P20 & 335.1 \\
P2R & 273.7 \\
P5 & 10.9 \\
G1 & 37.8 \\
G2 & 0.260 \\
G3 & 1.0 \\
G4 & 1.0 \\
\hline
\end{tabular}

rainfall during various seasons in the past, current and future RCP projected scenarios for 2020, 2050 and 2080 are presented in Tables $2(\mathrm{a}, \mathrm{b}, \mathrm{c})$. At Jorhat the average maximum temperature was higher by $0.4^{\circ} \mathrm{C}$ during summer and monsoon and $1.2^{\circ} \mathrm{C}$ during winter in $2009-2013$ (field experimentation period) over 1991-2007. The maximum and minimum temperatures for different RCP projections were compared with temperature conditions prevailed during the experimentation period. The various RCPs taken together, maximum temperature is likely to go up by $2.7,1.2$ and $1.3^{\circ} \mathrm{C}$ during summer, monsoon and post monsoon, respectively, and decrease by $1.0^{\circ} \mathrm{C}$ during winter of 2020 over average temperatures of the same seasons for the period of 20092013. By 2050 the magnitude of increase in maximum temperature is likely to be $3.1,1.5$ and $1.5^{\circ} \mathrm{C}$ during summer, monsoon and post monsoon, respectively, with decrease in winter by $0.7^{\circ} \mathrm{C}$. Projections for 2080 suggest a further increase of maximum temperature in all the seasons by 4.0 , $2.4,2.5$ and $0.4^{\circ} \mathrm{C}$ during summer, monsoon, post monsoon and winter, respectively. Like maximum temperature, the minimum temperature has also shown increasing trend at Jorhat. Considering all the RCP projections together, the ranges of increase in minimum temperature are $1.2^{\circ} \mathrm{C}$ in post monsoon to $1.9^{\circ} \mathrm{C}$ in summer $(2020) ; 1.4^{\circ} \mathrm{C}$ in monsoon and post monsoon to $2.3^{\circ} \mathrm{C}$ in summer $(2050)$ and $1.5^{\circ} \mathrm{C}$ in winter to $3.3^{\circ} \mathrm{C}$ in summer (2080) over 2009-2013.

With respect to seasonal rainfall, during 2009-2013, Jorhat experienced 14.6 and $4.3 \%$ higher rainfall during summer and monsoon seasons, respectively, where as drastic reduction in post monsoon and winter by 51 and $171.9 \%$, respectively, over average values of 1991-2008. The rainfall for different RCP projections were compared with the rainfall received during the experimentation period. In 2020, 2050 and 2080, Jorhat is likely to receive higher amount of rainfall 
Table 5:Projected rice (Cv. Mahsuri) yield variability at Jorhat under different RCP scenarios and dates of sowing over current condition (2009-2013)

\begin{tabular}{|c|c|c|c|c|c|c|}
\hline \multirow[t]{2}{*}{ Periods } & \multirow{2}{*}{$\begin{array}{c}\text { Observed grain } \\
\text { yield }\left(\mathrm{kg} \mathrm{ha}^{-1}\right) \\
(2009-2013)\end{array}$} & \multicolumn{5}{|c|}{$\%$ Change in grain yield over $2009-2013$} \\
\hline & & $\mathrm{RCP} 2.6$ & $\mathrm{RCP} 4.5$ & RCP 6.0 & $\mathrm{RCP} 8.5$ & Mean \\
\hline $2020 \mathrm{D} 1 *$ & & -14.4 & -14.8 & -27.5 & -27.5 & -21.0 \\
\hline 2050D1 & & -14.5 & -34.3 & -17.1 & -35.3 & -25.0 \\
\hline 2080D1 & & -9.3 & -33.8 & -27.0 & -23.7 & -23.0 \\
\hline Mean & 2600 & -12.7 & -27.6 & -23.9 & -28.8 & -23.3 \\
\hline 2020D2 & & -27.6 & -29.5 & -36.7 & -36.7 & -33.0 \\
\hline 2050D2 & & -43.9 & -43.5 & -44.1 & -44.8 & -44.0 \\
\hline 2080D2 & & -31.1 & -38.9 & -35.9 & -48.8 & -39.0 \\
\hline Mean & 4594 & -34.2 & -37.3 & -38.9 & -43.4 & -38.5 \\
\hline 2020D3 & & -21.1 & -26.8 & -14.0 & -14.0 & -19.0 \\
\hline 2050D3 & & -56.6 & -58.9 & -64.0 & -61.9 & -60.0 \\
\hline 2080D3 & & -14.9 & -5.5 & -12.2 & 4.3 & -7.0 \\
\hline Mean & 3443 & -30.9 & -30.4 & -30.1 & -23.9 & -28.8 \\
\hline
\end{tabular}

*D1 ( $3^{\text {rd }}$ week of May), D2 ( $2^{\text {nd }}$ week of June $)$ and D3 ( $1^{\text {st }}$ week of July) are the dates of transplanting

in all the seasons compared to present mean rainfall. The various RCPs taken together, the rainfall will be higher at Jorhat by $46.3,19.3,27.4$ and $118.0 \%$ during summer, monsoon, post monsoon and winter, respectively, in 2020; by 2050 , magnitudes will be higher by $64.2,26.1,28.6$ and $77.9 \%$, respectively in the same order of the seasons. Projections for 2080 suggest a similar trend, but with reduced magnitude of rainfall compared to 2020 and 2050 . There by impacting the production scenario, mostly in rainfed regions (Terink et al., 2013).

\section{Calibration and validation of CERES-Rice}

The CERES-Rice model calibration (2009-11) and validation (2012-13) results along with the genotype coefficients developed for rice cv. Mahsuri are presented in Table 3 and 4 . The observed and simulated anthesis and maturity days and grain yield under calibration runs exhibited a very good agreement with acceptable D-stat values, which are above 0.5. During model validation, percent difference between observed and simulated grain yields were $9.0,8.9$ and $9.0 \%$, for dates of transplanting viz. D1 ( $3^{\text {rd }}$ week of May), D2 ( $2^{\text {nd }}$ week of June) and D3 ( $1^{\text {st }}$ week of July), respectively. Similarly, days for Anthesis and maturity also showed close agreement between observed and predicted values. The calibration and validation results suggest suitability of the model for further yield projections under futuristic scenarios.

\section{Simulated rice yield variability under future $R C P$ projections}

The observed mean grain yield for first (D1), second (D2) and third (D3) dates of transplanting were 2600, 4594 and $3443 \mathrm{~kg} \mathrm{ha}^{-1}$, respectively, during 2009-2013 and rice yield under various RCP projections were compared with the present yield to estimate yield variability in future (Table $5)$. The results reveal that there is large negative deviation of projected rice yield in all scenarios compared to the mean observed grain yield. Under various scenarios, percent deviations in projected yield ranged from - 12.7 (RCP 2.6) to $-28.8 \%$ (RCP 8.5 ); -34.2 (RCP 2.6) to -43.4\% (RCP 8.5) and 23.9 (RCP 8.5 ) to $-30.9 \%$ ( RCP 2.5 ) in first, second and third dates of transplanting, respectively, over observed mean yield of 2009-2013. Considering different transplanting dates, the maximum mean yield reduction is likely in second transplanting date (-38.5\%), followed by third (-28.8\%) and first one $(-23.3 \%)$ under various RCP projections at Jorhat. There is likelyincrease in maximum and minimum temperature at Jorhat during the rice growing season (Monsoon and post monsoon). The projected magnitude of increase in maximum temperature is ranged from $1.2(2020)$ to $2.4(2080)$ 
${ }^{\circ} \mathrm{C}$, during monsoon and $1.3(2020)$ to $2.5(2080){ }^{\circ} \mathrm{C}$, during post monsoon seasons. The minimum temperature has also sown similar trend of increase. Though there is likely increase in seasonal rainfall in 2020 and 2050, but by 2080 the rainfall is likely to decrease compared to present mean rainfall. These factors, associated with temperature and rainfall, may definitely be attributedfor reduction in projected rice grain yield under various scenarios.

\section{CONCLUSION}

High magnitude in both maximum and minimum temperatures under all the RCPs at Jorhat suggests increasing levels of water and heat stresses during crop growth period. High minimum temperature during the reproductive stages may lead to minimization of economic yield. The long duration cultivars of rice which use to flower and ripen during the months of October and November are likely to face terminal season drought if not planted early. As summer has seen increase in rainfall at Jorhat, it may be wise to advance the sowing/transplanting of long duration rice from normal June-July to May-June. But considering the RCP projections, the rainfall at Jorhat is likely to increase by 2020,2050 and 2080 in all the seasons. Excessive rain and flooding of matured paddy fields may cause further loss of yield in future scenarios. The above analysis suggests that the second date of transplanting ( $2^{\text {nd }}$ week of June) is most vulnerable to possible climate change followed by third date of transplanting ( $1^{\text {st }}$ week of July). As yield reduction is lowest in the first date of transplanting ( $3^{\text {rd }}$ week of May), with this present cultivar, it will be appropriate to go for early season ( $3^{\text {rd }}$ week of May) sowing/transplanting of rice at Jorhat to minimize climate induced yield loss considering the future scenarios.

\section{REFERENCES}

Anonymous. (2015). Emissionscenarios. Retrieved from WMO web site as on 15-09-2015. https://www.wmo.int/pages/ themes/climate/emission_scenarios.php

Auffhammer, M., Ramanathan, V. and Vincent, J.R. (2012). Climate change, the monsoon, and rice yield in India.
Climatic Change, 111:411-424. DOI 10.1007/s10584011-0208-4.

Commission for Agricultural Costs and Prices. (2010). Report on price policy for Kharif crops of 2010-2011 season. Government of India, New Delhi.

Dash, S.K., Kulkarni, M.A., Mohanty, U.C. and Prasad, K. (2009). Changes in the characteristics of rain events in India. JGeophys Res, 114:D10109

IPCC.(2013). Climate Change 2013: The Physical Science Basis. Contribution of Working Group I to the Fifth Assessment Report of the IntergovernmentalPanel on Climate Change [Stocker, T.F., D. Qin, G.-K. Plattner, M. Tignor, S.K. Allen, J. Boschung, A. Nauels, Y. Xia, V. Bex and P.M. Midgley(eds.)]. Cambridge University Press, Cambridge, United Kingdom and New York, NY, USA, pp. 1535.

IPCC. (2014). Climate Change 2014: Synthesis Report. Contribution of Working Groups I, II and III to the Fifth Assessment Report of the Intergovernmental Panel on Climate Change[Core Writing Team, R.K. Pachauri and L.A. Meyer(eds.)]. IPCC, Geneva, Switzerland, 151 pp.

Manoj-Kumar. (2011). Evidences, Projections and Potential Impacts of Climate Change on Food Production in Northeast India. Indian J. Hill Frm., 24(1\&2): 1-10.

Ramesh, K.V. and Goswami,P. (2007)Reduction in temporal and spatial extent of the Indian summer monsoon. Geophys Res Lett, 34:L23704.

Ravindranath, N.H., Sandhya Rao, Nitasha Sharma, Malini Nair, Ranjith Gopalakrishnan, Ananya S. Rao, Sumedha Malaviya, Rakesh Tiwari, Anitha Sagadevan, Madhushree Munsi, Niharika Krishna and Govindasamy Bala. (2011). Climate change vulnerability profiles for North east India.Curr. Sci, 101(3):384-94.

Saikia, U.S. Goswami, B., Rajkhowa, D.J., Venkatesh, A., Kausalya Ramachandran, Rao, V.U.M, Venkateswarlu, B. and Ngachan, S.V. (2013). Shift in monsoon rainfall pattern in the North Eastern region of India post 1991. J. Agrometeorol,15 (2): 162-164. 